\title{
Obituaries
}

\section{Loren Mosher}

Psychiatrist who espoused drug-free treatment for schizophrenia

The US psychiatrist Loren Mosher spent his entire professional career seeking more humane and effective treatment for people with a diagnosis of schizophrenia. This caused him to be cast as a maverick and to be marginalised by mainstream psychiatry.

As an advocate for patients' rights Mosher took an approach that was derived from the "moral treatment" of mentally ill people, a tradition characterised by Philippe Pinel when he removed the chains from the men held in the Bicêtre Hospital in Paris in 1797.

Mosher started a heated debate when he publicly resigned in 1998 from the American Psychiatric Association (APA)-which he called the American Psychopharmaceutical Association-charging that "psychiatry has been almost completely bought out by the drug companies."

An honours graduate of Harvard University, Mosher served from 1968 to 1980 as the first chief of the Center for Studies of Schizophrenia of the National Institutes of Mental Health. He was the founder and first editor in chief of Schizophrenia Bulletin, and he coauthored the textbook Community Mental Health: Principles and Practice, which has been translated into five languages, and wrote or edited numerous scientific articles.

The consequences of his opposition to the influence of drug companies over medicine and his insistence on non-drug measures to help patients took a toll. In a 2003 interview with the San Diego Weekly Reader he said, "I am completely marginalized in American psychiatry. I am never invited to give grand rounds. I am never invited to give presentations ... in the United States."

Dr Mosher's early research into identical twins and schizophrenia convinced him that genes alone could not explain the onset of schizophrenia. By ignoring environmental and psychosocial factors, the psychiatric establishment was guilty, he said, of reducing schizophrenia to a "mechanistic" brain disease model. The result, he said, is that, "We're so busy with drugs that you can't find a nickel being spent on [non-drug] research."

While doing research training at the Tavistock Clinic in London from 1966 to

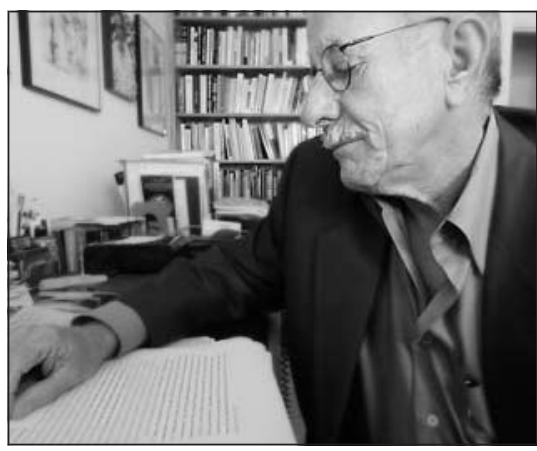

1967 Mosher developed an interest in alternative treatments for schizophrenia. He visited Anna Freud and R D Laing and was influenced by Laing's view that schizophrenia was a reaction to an unbearable situation.

Mosher worked closely for years with many advocacy groups, including the "psychiatric survivor" group MindFreedom International. Its director, David Oaks, said, "There are a number of psychiatrists who support our work, but few who simply liked hanging out with survivors the way Loren did. Loren was a real hero. He was willing to confront the mental health system, and he always did it with great humour and wit and intelligence."

In the early 1970s Mosher founded an innovative home-like treatment programme for patients with newly diagnosed schizophrenia called the Soteria (Greek for deliverance) Project. He believed that the violent atmosphere of mental hospitals and the routine use of "toxic" drugs were counter to a healthy recovery. Staff members at the project were encouraged to treat residents as peers and to share household chores. The programme was designed to create "an environment that respected and tolerated individual differences and autonomy." The Soteria Project closed in 1983 when funding dried up.

Mosher had a far more nuanced view of the use of drugs than is generally admitted. Though he often emphasised environmental factors, his writings indicate that he believed a delicate interplay between inherent "vulnerability" and environmental challenges could tip a patient over into schizophrenia or what he preferred to call "disturbed and disturbing" behaviour. Far from rejecting drugs altogether, he insisted that they be used as a last resort-and then in far lower doses than currently is usual in the United States.

More important, perhaps, than his resistance to drug use was his interest in non-drug treatments. Residents at the Soteria Project were treated with a quiet, calming environment. Neuroleptic drugs were used only when the patient became violent or suicidal. If the patient made no progress after six weeks and consented to drug treatment neuroleptics could be prescribed at low doses. Overall, 58\% of Soteria patients were treated at some point with antipsychotic drugs, but only 19\% were continuously maintained on the drugs, compared with $94 \%$ of patients who receive the usual care.

A 2003 report on outcomes among patients who were randomised to usual care or to the Soteria treatment, written by Mosher and Dr J R Bola, concluded that overall the Soteria patients did as well as or better than patients assigned to usual care. Critics immediately raised questions about possible study biases and its statistical analyses.

If there is one measure of his work, however, that transcends statistical argument, it is that surveys of patients treated at Soteria show that they simply felt better. They liked how they were treated better than in hospital. And if the mind is something that has value beyond its ability to function in a way that allows its owner to work or live independently, then feeling better is as good a goal-perhaps as moral a goal-as any.

Loren Mosher leaves his second wife of 16 years, Judith Schreiber; three children, Hal, Tim, and Missy Galanida; and two brothers, Roger and Harold. [JEANNE LENZER]

Loren Richard Mosher, clinical professor of psychiatry University of California at San Diego Medical School (b Monterey, California, 1933; q Harvard University Medical School, Boston, United States, 1961), died from liver cancer in Berlin on 10 July.

Longer versions of these obituaries are available on bmj.com 


\section{Leslie MacDonald Craig}

Former general practitioner Corby and Inveraray (b Glasgow 1918; q Glasgow 1952), d 12 June 2004.

Leslie began studying medicine in 1939, but the fall of France caused him to quit his course and join the army. He served in west Africa and India, becoming a regimental sergeant major. At the end of the second world war he returned to medicine, and after qualifying settled in Corby as a general practitioner. He later became the GP serving the communities of Inveraray and Furnace, remaining there until retirement in 1983 . $\mathrm{He}$ undertook valuable research into the medical history of the area, and the lives and careers of local doctors. Leslie was a keen and skilled piper, and was awarded the MBE for services to piping in 2000. He leaves a wife, Ann, and a son. [James Beaton]

\section{William ("Bob") McIntosh Sinclair Ironside}

Former consultant otolaryngologist Huddersfield and Halifax, West Yorkshire (b Hong Kong 1923; $q$ Aberdeen 1945; FRCS, FACCP), died from metastatic prostate cancer on 12 May 2004. Bob did a year's research in Chicago and enjoyed it so much that he worked there for four years before returning to Yorkshire to devote 32 years to research and innovation in areas as diverse as antral cancer, hypophysectomy, bronchoscopy, and middle ear transplants. He taught and lectured at home and abroad and became president of the otology section of the Royal Society of Medicine. Bob was also an exceptional sportsman, representing Scottish Universities in rugby, golf, and swimming. He became a member of the Senior Golfers' Society and represented Great Britain in America. He leaves a wife, Joyce; two daughters; two stepsons; and his grandchildren. [G J C SMELT]

\section{Angus Henry Luscombe}

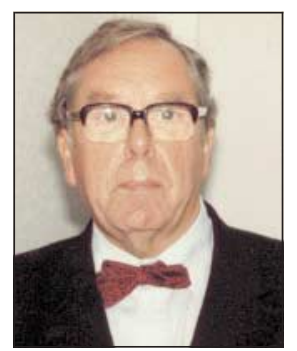

Former general practitioner Wilmslow, Cheshire (b Devon 1926; q St Bartholomew's Hospital, London, 1955), d 4 May 2004.

Angus was called up in 1944 and commissioned into the Gordon Highlanders. He saw active service in France in 1945 and later as a counter-terrorist officer in Palestine. Leaving the army in 1948 he entered St Bartholomew's Hospital Medical School. Joining a general practice in Wilmslow in 1958, he developed one of the first multiskilled practices in Cheshire. Active in local medical management and politics he served as vice chairman of the Macclesfield Health Authority and treasurer of the local medical committee. He retired in 1989 but continued to lecture widely. He leaves a wife, Ann, and two children. [F E Luscombe, H C MaCDONALD]

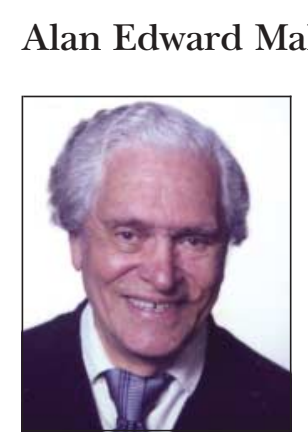

Former general practitioner Southampton (b London 1922; q London 1946; FRCGP), died on 14 July from a massive stroke.

He played hockey with distinction for the hospital, London University, United Hospitals, and English Universities. After two years' service in the Royal Air Force he settled in Southampton, where he was later appointed life honorary teacher in general practice to the medical school. He was the first GP tutor in Southampton responsible for postgraduate GP education. He was elected a fellow of the BMA. After retirement he settled in Bristol, thoroughly enjoying his life there, particularly the excellent music available in the city. He leaves three daughters and seven grandchildren. [JuDY MaLONE]

\section{Jimmy Foden Shroff}

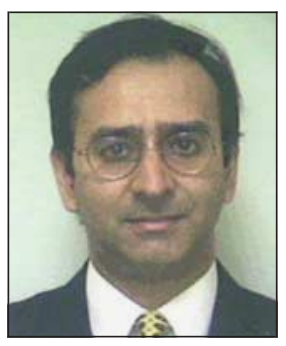

Consultant in obstetrics and gynaecology Tameside General Hospital (b Epsom 1959; q St Bartholomew's Hospital, London, 1983; MRCGP, FRCS, MRCOG), died from a pancreatic tumour on 13 November 2003. Jimmy Foden Shroff was profoundly interested in all aspects of medicine, and this attracted him into general practice. After obtaining his MRCGP he decided to train in obstetrics and gynaecology. He became a consultant in obstetrics and gynaecology at Tameside General Hospital in 2000. With a colleague he developed the West Pennine Gynaecological Oncology Unit. He lectured in the department, the postgraduate centre, and in the Greater Manchester Gynaecology Oncology Group. Jimmy had a variety of interests, including swimming, cycling, maintaining his own cars, do it yourself, model railways, and scouting. He leaves a wife, Liz, and three children. [N G HoDGEs]

\section{Gordon William Taylor}

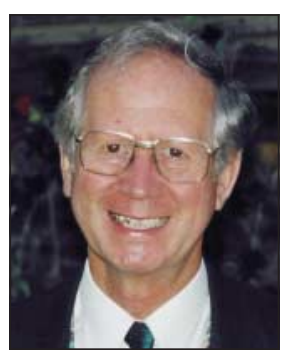

Former general practitioner Reading (b 1928; $q$ Manchester 1952; MBE, FRCGP), died from bronchopneumonia and Parkinson's disease on 18 June 2004.

Five years after qualification Gordon settled in Reading as a general practitioner, helping to build up a practice on a new housing estate. In 1981 he became a magistrate. He was actively involved in medical politics, and chaired the BMA ethics committee for a number of years. He had a special interest in the training of medical secretaries, and in 1997 was made a fellow of the Association of Medical Secretaries and Practice Administrators. Parkinson's disease forced him to take early retirement in 1988. A dedicated Christian, he worshipped at the same church for over 50 years. He leaves a wife, Joan; three children; and seven grandchildren. [Phil Simmons]

\section{Nora Kathleen Woll}

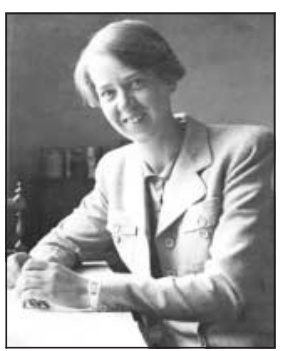

Former general practitioner Bottesford, Leicestershire (b Tynemouth 1914; q Durham 1938; MBE), died from old age on 15 May 2004. Kathleen was working as a house officer when the second world war broke out. As the Royal Army Medical Corps was not taking on women doctors, she enlisted in the Indian Medical Service, where she became a major. After the war she did postgraduate training in child health, working in London and Newcastle upon Tyne. She then became a singlehanded family practitioner for over 30 years. She continued her interest in child health by introducing antenatal and immunisation clinics. In 1956 she was found to have a meningioma. She underwent pioneering surgery, leaving her with a dense right hemiplegia and facial palsy. She taught herself to write and give injections with her left hand, and resumed her work. [PENELLA J Woll] 